\title{
Faktor-Faktor yang Berhubungan dengan Infeksi Oportunistik Tuberkulosis pada Pasien HIV di RSPI Sulianti Saroso Tahun 2015-2019
}

\author{
Factors Related to the Opportunistic Tuberculosis Infection in HIV Patients at Sulianti \\ Saroso Infectious Disease in 2015-2019
}

\author{
Amelia Pradipta1, Mondastri Korib Sudaryo', Adria Rusli ${ }^{2}$ \\ 1 Departemen Epidemiologi, Program Studi Kesehatan Masyarakat, Fakultas Kesehatan \\ Masyarakat Universitas Indonesia \\ 2 RSPI Prof. Dr. Sulianti Saroso, Kementerian Kesehatan Republik Indonesia
}

*Korespodensi Penulis:

Amelia Pradipta,

Email: ameliapradipta15@gmail.com

\begin{abstract}
Abstrak
Latar belakang: Human Immunodeficiency Virus (HIV) menjadi masalah utama kesehatan global yang sedang dihadapi oleh berbagai negara, termasuk Indonesia. Penderita HIV lebih rentan untuk terkena infeksi oportunistik, salah satunya tuberkulosis. Penelitian ini bertujuan untuk mengidentifikasi faktor-faktor yang berhubungan dengan infeksi oportunistik tuberkulosis pada pasien HIV di RSPI Prof. Dr. Sulianti Saroso tahun 2015-2019. Metode: Studi case control dilakukan dengan menggunakan data register praART dan rekam medis. Jumlah sampel sebanyak 465 responden, yang terdiri dari 155 kasus dan 310 kontrol. Analisis yang dilakukan adalah analisis univariat, bivariat menggunakan chi-square, dan multivariat menggunakan regresi logistik. Hasil: Hasil uji regresi logistik menunjukkan ada hubungan yang bermakna secara statistik antara stadium HIV dengan infeksi oportunistik tuberkulosis $(\mathrm{OR}=33,03 ; 95 \% \mathrm{Cl}$ : 14,96 - 72,89) dengan nilai $p<0,001$, tetapi tidak ada hubungan yang bermakna secara statistik antara usia, jenis kelamin, jumlah CD4, jumlah viral load, pendidikan, status bekerja, perilaku seks berisiko, transfusi darah, dan penggunaan napza suntik dengan infeksi oportunistik tuberkulosis. Kesimpulan: Stadium HIV merupakan faktor determinan infeksi oportunistik tuberkulosis pada pasien HIV. Saran: Diperlukan skrining awal mendeteksi TB pada setiap stadium HIV khususnya pada stadium lanjut (III-IV) yang melakukan kunjungan di klinik Pokja.
\end{abstract}

Kata Kunci: Stadium HIV, Infeksi Oportunistik, Tuberkulosis, HIV/AIDS

\begin{abstract}
Background: Human Immunodeficiency Virus (HIV) is a major global health problem that is being faced by many countries, including Indonesia. HIV patients are more susceptible to opportunistic infections, one of which is tuberculosis. This research aimed to identify the factors associated with the opportunistic tuberculosis infection in HIV patients at RSPI Prof. Dr. Sulianti Saroso throughout the 2015-2019 period. Method: A case-control study was conducted by using data from the pre-ART register data and medical records. The sample was 465 respondents, consisting of 155 cases and 310 controls. The types of analysis conducted were the univariate analysis and the bivariate analysis using the chi-square test, and the multivariate analysis using logistic regression. Results: The logistic regression test results showed that there was a statistically significant relationship between the HIV stage and the opportunistic tuberculosis
\end{abstract}


infection (OR = 33.03; 95\% Cl: 14.96-72.89) with a $p$ value of $<0.001$, but there was no statistically significant relationship between age, sex, CD4 count, viral load count, education, employment status, risky sexual behavior, blood transfusion, and the use of injected drugs and the opportunistic tuberculosis infection. Conclusion: The HIV stage is a determinant factor for the opportunistic tuberculosis infection in HIV patients. Suggestion: It is essential to conduct early screening to detect TB at each stage of HIV, especially at an advanced stage (stage III-IV), on patients who visit the Working Group clinic.

Keywords: HIV stage, opportunistic infection, tuberculosis, HIVIAIDS

\section{Pendahuluan}

Human Immunodeficiency Virus (HIV) menjadi masalah utama kesehatan global yang sedang dihadapi oleh berbagai negara, yaitu diestimasikan menyebabkan 770.000 kematian. Secara global, diestimasikan terdapat 37,9 juta penderita HIV dan 1,7 juta penderita baru yang terinfeksi HIV pada tahun 2018. Indonesia merupakan salah satu negara yang menghadapi permasalahan HIV, dengan 46.659 kasus infeksi HIV yang dilaporkan tahun 2018. Provinsi dengan kasus HIV terbanyak di Indonesia adalah DKI Jakarta sebesar 14,8\% (6.896 kasus). ${ }^{(1)}$

Virus ini menyerang dan merusak fungsi sel-sel imun tubuh dan melemahkan sistem pertahanan tubuh terhadap infeksi dan beberapa jenis penyakit kanker, biasanya diukur dari penurunan jumlah sel CD4. Tahap akhirnya adalah Acquired Immunodeficiency Syndrome (AIDS) yang dapat berlangsung selama 2-15 tahun. Penularan virus ini dapat melalui perilaku seks tidak aman, penggunaan alat suntik bersama, transfusi darah, dan kegiatan medis yang melibatkan penggunaan pisau/jarum yang tidak steril. ${ }^{(2)}$ Infeksi HIV dalam tubuh dapat didiagnosis melalui Rapid Diagnostic Tests (RDTs) dan dapat diobati dengan antiretroviral therapy (ART), yaitu kombinasi dari 3 jenis atau lebih obat antiretroviral.

\section{United Nations General Assembly} menetapkan target berakhirnya kejadian epidemik HIV/AIDS pada tahun 2030, yang kemudian menjadi visi penanggulangan HIV dan AIDS di Indonesia. ${ }^{(3)}$ Selain itu, terdapat target target 90-90-90 artinya 90\% penderita HIV mengetahui statusnya, $90 \%$ diobati, dan $90 \%$ virus HIV dalam tubuh berhasil ditekan. ${ }^{(4)}$ Berdasarkan data analisis perkembangan target 90-90-90 di Indonesia tahun 2018, masih terdapat $51 \%$ penderita HIV yang mengetahui statusnya dan hanya $33 \%$ diantaranya yang melakukan pengobatan ART. ${ }^{(5)}$

Penurunan sistem imun tubuh pada penderita HIV yang tidak melakukan pengobatan dapat meningkatkan risiko terjadinya infeksi oportunistik. Infeksi oportunistik 
merupakan infeksi yang umumnya terjadi dan lebih parah pada orang dengan sistem imun tubuh yang rendah, termasuk orang dengan HIV/AIDS (ODHA). ${ }^{(6)}$ Infeksi oportunistik yang sering ditemukan di Indonesia adalah Tuberkulosis, Kandidiasis oral, diare, Pneumocystis Pneumonia (PCP), dan Pruritic Papular Eruption (PPE). Proporsi infeksi oportunistik tertinggi di Indonesia adalah Tuberkulosis (11.513 kasus). (7) Infeksi Tuberkulosis apabila tidak segera ditangani dapat berkembang menjadi penyakit Tuberkulosis aktif, diperkirakan secara global terdapat 862.000 kasus baru penyakit tuberkulosis pada penderita HIV. Penyakit Tuberkulosis ini dapat menyebabkan kematian pada penderita HIV, yaitu pada tahun 2018 diestimasikan terdapat 251.000 kematian akibat tuberkulosis pada penderita HIV. ${ }^{(8)}$

Salah satu rumah sakit yang menangani banyak pasien HIV adalah RSPI Prof. Dr. Sulianti Saroso. Sebuah penelitian yang dilakukan di RSPI Sulianti Saroso menunjukkan jenis infeksi oportunistik terbanyak adalah infeksi oportunistik tuberkulosis, sebanyak 62 kasus $(67,4 \%)$. ${ }^{(9)}$ Tujuan dari penelitian ini adalah untuk mengidentifikasi faktor-faktor yang berhubungan dengan infeksi oportunistik tuberkulosis (TB) pada pasien HIV/AIDS di RSPI Prof. Dr. Sulianti Saroso. Pengetahuan mengenai faktor-faktor yang berhubungan dengan infeksi oportunistik tuberkulosis pada pasien HIV/AIDS ini diharapkan dapat meningkatkan kesadaran pasien HIV yang berada pada kelompok risiko untuk melakukan deteksi dini tuberkulosis.

\section{Metode}

Penelitian ini menggunakan desain penelitian case-control, dilakukan di RSPI Prof. Dr. Sulianti Saroso pada bulan Februari 2020. Jenis data yang dikumpulkan adalah data sekunder yaitu data register pra-ART dan rekam medis pasien HIV/AIDS. Populasi target dalam penelitian ini adalah seluruh penderita HIV/AIDS yang tercatat dalam data register pra-ART dan data rekam medis di klinik Pokja HIV/AIDS RSPI Sulianti Saroso tahun 2015-2019. Populasi kasus adalah pasien HIV/AIDS yang terkena infeksi oportunistik tuberkulosis (tb paru dan/atau to ekstra paru) di RSPI Sulianti Saroso tahun 2015-2019 (berdasarkan data form register praART saat kunjungan pertama). Sedangkan, populasi kontrol adalah pasien HIV/AIDS yang tidak terkena infeksi oportunistik dan pasien HIV/AIDS yang terkena infeksi 
oportunistik bukan tuberkulosis di RSPI

Sulianti Saroso tahun 2015-2019.

Pengambilan sampel berdasarkan kriteria inklusi yang telah ditentukan. Kriteria inklusi kasus yaitu responden penderita HIV/AIDS yang terkena infeksi oportunistik tuberkulosis paru dan/atau ekstraparu, serta tercatat dalam data register pra-ART dan rekam medis pada tahun 2015-2019 di RSPI Sulianti Saroso tahun 2015-2019. Untuk kelompok kontrol, kriteria inklusi yaitu responden penderita HIV/AIDS yang tidak terkena infeksi oportunistik dan penderita HIV/AIDS yang terkena infeksi oportunistik bukan tuberkulosis berdasarkan data register pra-ART dan register ART RSPI Sulianti Saroso tahun 2015-2019.

Pemilihan sampel kelompok kasus menggunakan metode total sampling, dengan jumlah sampel kasus 155 orang. Perbandingan kelompok kontrol dan kelompok kasus yang digunakan dalam penelitian ini adalah 2:1. Jadi, jumlah sampel kelompok kontrol dengan teknik simple random sampling adalah 310 orang. Kemudian, data dianalisis secara univariat, bivariat (uji chi square), dan multivariat (regresi logistik).

Hasil

Penelitian ini menunjukkan bahwa infeksi oportunistik yang paling banyak terjadi pada kelompok kasus adalah tuberkulosis non kombinasi, yaitu sebanyak 109 orang (70,3\%), dapat dilihat pada tabel 1. Infeksi tuberkulosis kombinasi yang paling sering terjadi pada kelompok kasus adalah kombinasi tuberkulosis dengan kandidiasis sebanyak 29 orang (16,8\%) dan kombinasi tuberkulosis dengan toxoplasmosis sebanyak 9 orang $(5,8 \%)$. Sedangkan, pada kelompok kontrol terdapat 248 orang (80\%) yang tidak ada infeksi oportunistik. Infeksi oportunistik yang paling banyak terjadi pada kelompok kontrol adalah infeksi oportunistik kandidiasis sebesar 7,7\% (24 orang) dan toxoplasmosis sebesar $6,8 \%$ (21 orang).

Tabel 1. Distribusi Infeksi Oportunistik pada Pasien HIV/AIDS di RSPI Prof. Dr. Sulianti Saroso Tahun 2015-2019

\begin{tabular}{lcccc}
\hline Infeksi Oportunistik & \multicolumn{2}{c}{ Kasus } & \multicolumn{2}{c}{ Kontrol } \\
\cline { 2 - 5 } & $\mathbf{n}$ & $\%$ & $\mathbf{n}$ & $\%$ \\
\hline Tuberkulosis & 109 & $70,3 \%$ & - & - \\
Tidak Ada Infeksi Oportunistik & - & - & 248 & $80 \%$ \\
Tuberkulosis + Kandidiasis (kombinasi) & 26 & $16,8 \%$ & 24 & $7,7 \%$ \\
Tuberkulosis + Toxoplasmosis (kombinasi) & 9 & $5,8 \%$ & 21 & $6,8 \%$ \\
Lain-lain & 11 & $7,1 \%$ & 17 & $5,5 \%$ \\
\hline Total & $\mathbf{1 5 5}$ & $\mathbf{1 0 0} \%$ & $\mathbf{3 1 0}$ & $\mathbf{1 0 0} \%$ \\
\hline
\end{tabular}


Tabel 2. Hasil Analisis Bivariat Terhadap Kejadian Infeksi Oportunistik Tuberkulosis pada Pasien HIV/AIDS di RSPI Prof. Dr. Sulianti Saroso Tahun 2015-2019

\begin{tabular}{|c|c|c|c|}
\hline Variabel & OR & $\mathrm{Cl} 95 \%$ & P Value \\
\hline \multicolumn{4}{|l|}{ Usia } \\
\hline$>30$ tahun & ref & & \\
\hline$\leq 30$ tahun & 1,22 & $0,83-1,80$ & 0,371 \\
\hline \multicolumn{4}{|l|}{ Jenis Kelamin } \\
\hline Perempuan & ref & & \\
\hline Laki-laki & 0,62 & $0,39-0,99$ & 0,062 \\
\hline \multicolumn{4}{|l|}{ Jumlah CD4 } \\
\hline$\geq 200 / \mathrm{mm}^{3}$ & ref & & \\
\hline$<200 / \mathrm{mm}^{3}$ & 4,12 & $2,54-6,68$ & $<0,001$ \\
\hline \multicolumn{4}{|l|}{ Stadium HIV } \\
\hline Stadium Awal (I-II) & ref & & \\
\hline Stadium Akhir (III-IV) & 33,02 & $14,96-72,89$ & $<0,001$ \\
\hline \multicolumn{4}{|l|}{ Jumlah viral load } \\
\hline$\leq 1000 / \mathrm{ml}$ & ref & & \\
\hline$>1000 / \mathrm{ml}$ & 3,48 & $1,17-10,36$ & 0,041 \\
\hline \multicolumn{4}{|l|}{ Pendidikan } \\
\hline Tinggi (SMP - Perguruan Tinggi) & ref & & \\
\hline Rendah (Tidak Sekolah-SD) & 3,16 & $1,64-6,08$ & 0,001 \\
\hline \multicolumn{4}{|l|}{ Status Bekerja } \\
\hline Bekerja & ref & & \\
\hline Tidak Bekerja & 3,36 & $2,2-5,13$ & $<0,001$ \\
\hline \multicolumn{4}{|l|}{ Perilaku Seks Berisiko } \\
\hline Homoseksual/Biseksual & ref & & \\
\hline Heteroseksual & 2,53 & $1,65-3,87$ & $<0,001$ \\
\hline \multicolumn{4}{|l|}{ Transfusi Darah } \\
\hline Tidak & ref & & \\
\hline Ya & 2,01 & $0,28-14,43$ & 0,604 \\
\hline \multicolumn{4}{|l|}{ Penggunaan Napza Suntik } \\
\hline Tidak & ref & & \\
\hline Ya & 3,08 & $0,86-11,08$ & 0,091 \\
\hline
\end{tabular}

Berdasarkan usia, responden kelompok kasus dan kontrol paling banyak berada pada kelompok usia 30 49 tahun, yaitu 83 orang $(53,6 \%)$ pada kelompok kasus dan 183 orang (59\%) pada kelompok kontrol. Responden pada kelompok kasus dan kontrol paling banyak berjenis kelamin laki-laki, yaitu 117 orang $(75,5 \%)$ pada kelompok kasus dan 258 orang $(83,2 \%)$ pada kelompok kontrol. Menurut tingkat pendidikan, responden pada kelompok kasus paling banyak memiliki tingkat pendidikan SMA yaitu 73 orang $(47,1 \%)$, sedangkan responden pada kelompok kontrol paling banyak memiliki tingkat pendidikan Perguruan Tinggi yaitu 175 orang (56,4\%). 
Berdasarkan status bekerja, responden pada kelompok kasus dan kontrol paling banyak adalah bekerja, yaitu masing-masing sebanyak 85 orang $(54,8 \%)$ dan 249 orang $(80,3 \%)$. Dilihat dari jumlah CD4, responden terbanyak memiliki jumlah CD4 $<200 / \mathrm{mm}^{3}$, yaitu masing-masing 130 orang $(83,9 \%)$ pada kelompok kasus dan 173 orang $(55,8 \%)$ pada kelompok kontrol. Responden kelompok kasus dan kelompok kontrol paling banyak berada pada stadium III, yaitu masingmasing 127 orang (81,9\%) dan 84 orang $(27,1 \%)$. Berdasarkan faktor risiko, responden pada kelompok kasus dan kontrol paling banyak memiliki faktor risiko heteroseksual, yaitu masing-masing 91 orang $(58,7 \%)$ dan 128 orang (41,3\%). Responden pada kelompok kasus dan kontrol paling banyak memiliki jumlah viral load $\leq 1000 / \mathrm{ml}$, yaitu masing-masing 29 orang $(72,5 \%)$ dan 55 orang $(90,2 \%)$.

Pada analisis multivariat, variabel yang dimasukkan sebagai kandidat adalah variabel yang menghasilkan $p<0,25$ pada analisis bivariat, terdiri atas variabel jenis kelamin, jumlah CD4, stadium HIV, jumlah viral load, pendidikan, status bekerja, perilaku seks berisiko, dan penggunaan napza suntik. Variabel-variabel ini dianalisis secara bersamaan dalam full model analisis multivariat. Variabel yang dipertahankan adalah variabel dengan nilai $p<0,05$. Apabila nilai $p$ lebih dari 0,05 , akan dikeluarkan secara bertahap dimulai dari variabel yang memiliki nilai $p$ paling besar hingga seluruh variabel memiliki nilai $p<0,05$ sehingga didapatkan model akhir analisis regresi logistik. Berdasarkan tabel 3, variabel jumlah CD4 memiliki nilai $\mathrm{p}$ paling besar sehingga akan dikeluarkan terlebih dahulu (Tabel 4).

Tabel 3. Full Model Analisis Multivariat

\begin{tabular}{lccc}
\hline Variabel & OR & $\mathbf{9 5 \%} \mathbf{C l}$ & $\mathbf{p ~ v a l u e ~}$ \\
\hline $\begin{array}{l}\text { Jenis } \\
\text { Kelamin }\end{array}$ & 1,46 & $0,34-6,31$ & 0,613 \\
\hline Pendidikan & 0,73 & $\begin{array}{c}0,03- \\
15,92\end{array}$ & 0,841 \\
\hline $\begin{array}{l}\text { Status } \\
\text { Bekerja }\end{array}$ & 1,30 & $0,39-4,30$ & 0,669 \\
\hline $\begin{array}{l}\text { Jumlah } \\
\text { CD4 }\end{array}$ & 0,88 & $0,23-3,43$ & 0,850 \\
\hline $\begin{array}{l}\text { Stadium } \\
\text { HIV }\end{array}$ & 24,69 & $\begin{array}{c}4,24- \\
143,91\end{array}$ & $<0,001$ \\
\hline $\begin{array}{l}\text { Jumlah } \\
\text { viral load }\end{array}$ & 2,14 & $0,55-8,26$ & 0,270 \\
\hline $\begin{array}{l}\text { Perilaku } \\
\text { Seks } \\
\text { Berisiko }\end{array}$ & 1,86 & $0,48-7,28$ & 0,373 \\
\hline
\end{tabular}

Tabel 4. Model Akhir Analisis Multivariat

\begin{tabular}{lccc}
\hline \multicolumn{1}{c}{ Variabel } & OR & $\mathbf{9 5 \%} \mathbf{C l}$ & $\begin{array}{c}\boldsymbol{p} \\
\text { value }\end{array}$ \\
\hline $\begin{array}{l}\text { Stadium HIV } \\
\begin{array}{l}\text { Stadium Awal } \\
\text { (I-II) }\end{array}\end{array}$ ref & & \\
$\begin{array}{l}\text { Stadium Akhir } \\
\text { (III-IV) }\end{array}$ & 33, & $14,96-$ & $<0,001$ \\
\hline
\end{tabular}


Berdasarkan tabel 4, hasil model akhir analisis multivariat menunjukkan bahwa variabel stadium HIV merupakan variabel yang paling bermakna berhubungan dengan kejadian infeksi oportunistik tuberkulosis pada pasien HIV/AIDS dengan OR 33,03 (95\% Cl: 14,96 $72,89)$, artinya odds terjadinya infeksi oportunistik tuberkulosis 33,03 kali lebih besar pada pasien HIV/AIDS di stadium akhir (III-IV).

\section{Pembahasan}

Hasil analisis multivariat dengan menggunakan uji regresi logistik menunjukkan ada hubungan yang bermakna secara statistik $(p<0,001)$ antara stadium HIV dengan infeksi oportunistik tuberkulosis. Pasien HIV yang berada pada stadium akhir (stadium III hingga stadium IV) memiliki odds 33,03 kali lebih besar untuk terkena infeksi oportunistik tuberkulosis (95\% Cl: 14,96 - 72,89). Sebuah penelitian serupa di Khartoum State, Sudan menunjukkan bahwa stadium III dan stadium IV merupakan salah satu faktor kuat yang menentukan terjadinya infeksi tuberkulosis pada pasien HIV. Dalam penelitian tersebut, pasien HIV stadium III dan stadium IV meningkatkan odds infeksi oportunistik tuberkulosis 5,86 kali (OR=5,86 ; 95\% Cl: $1,88-17,96)$ dengan nilai $p<0,01$. Penelitian lain dengan desain studi kohort retrospektif di Arba Minch General Hospital, Ethiopia, menunjukkan bahwa pasien HIV yang berada pada stadium III dan IV 20 dan 22 kali meningkatkan odds tuberkulosis dibandingkan dengan pasien HIV pada stadium I. ${ }^{(15)}$ Infeksi tuberkulosis pada pasien HIV berhubungan erat dengan terjadinya penurunan sistem imun tubuh. Semakin meningkatnya stadium HIV, sistem imun tubuh akan semakin menurun sehingga hal ini dapat meningkatkan risiko terjadinya infeksi oportunistik tuberkulosis. ${ }^{(12)}$

Hasil analisis bivariat menunjukkan bahwa odds terjadinya infeksi oportunistik tuberkulosis 1,22 kali lebih besar pada kelompok usia $\leq 30$ tahun, namun variabel ini tidak memiliki hubungan yang bermakna dengan kejadian infeksi oportunistik tuberkulosis karena tidak dapat diikutsertakan dalam analisis multivariat. Sebuah penelitian yang dilakukan di tujuh provinsi (Sumatera Utara, Sumatera Barat, Kepulauan Riau, Sulawesi Selatan, Sulawesi Utara, Maluku, dan Papua) dengan analisis bivariat menunjukkan bahwa semakin muda kelompok subjek dengan HIV semakin besar risiko untuk terkena infeksi oportunistik tuberkulosis karena pasien HIV pada kelompok usia muda ( $\leq 30$ tahun) cenderung lebih terpapar pada faktor risiko TB. ${ }^{(10)}$ 
Hubungan jenis kelamin dengan kejadian infeksi oportunistik tuberkulosis di RSPI Prof. Dr. Sulianti Saroso tahun 2015-2019 tidak bermakna, namun odds terjadinya infeksi oportunistik tuberkulosis 1,46 kali lebih besar pada laki-laki. Hasil penelitian ini didukung oleh sebuah studi potong lintang yang dilakukan di tujuh provinsi di Indonesia. Dalam penelitian tersebut menunjukkan bahwa ada hubungan bermakna antara jenis kelamin dengan kejadian infeksi oportunistik tuberkulosis, yaitu penderita HIV laki-laki mempunyai risiko 24\% lebih tinggi terinfeksi tuberkulosis (TB). ${ }^{(10)}$ Berdasarkan Survei Prevalensi Tuberkulosis di Indonesia tahun 2013-2014, prevalensi tuberkulosis pada laki-laki 3 kali lebih tinggi dibandingkan dengan perempuan. Hal ini terjadi akibat lakilaki lebih terpapar pada faktor risiko TB yaitu merokok. Dari seluruh partisipan laki-laki yang terkena tuberkulosis, terdapat $68,5 \%$ yang merokok. ${ }^{(11)}$

Dalam analisis bivariat, odds terjadinya infeksi oportunistik tuberkulosis 4,12 kali lebih besar pada pasien HIV dengan jumlah CD4 $<200 / \mathrm{mm}^{3} \quad(95 \%$ Cl: 2,54 - 6,68) dengan hubungan yang bermakna secara statistik. Sebuah studi case control di Khartoum State, Sudan menunjukkan bahwa terdapat hubungan yang bermakna antara jumlah CD4 dengan infeksi oportunistik tuberkulosis pada pasien HIV. Dalam penelitian tersebut pasien HIV dengan jumlah CD4 <200/mm³ meningkatkan odds terjadinya infeksi oportunistik tuberkulosis 4,81 kali lebih besar (95\% Cl: 1,57 - 15,26). ${ }^{(12)}$ Penelitian lain di Nigeria yang menggunakan desain studi kohort retrospektif menunjukkan bahwa pasien HIV dengan jumlah CD4 $<200 / \mathrm{mm}^{3}$ lebih berisiko untuk terkena infeksi tuberkulosis. Artinya, semakin rendah kadar CD4 maka semakin tinggi risiko TB pada pasien HIV. Kadar CD4 yang rendah menunjukkan adanya penurunan sistem kekebalan tubuh sehingga tubuh lebih rentan terhadap infeksi. ${ }^{(13)}$ Selain itu, penelitian yang dilakukan di salah satu RS Pemerintah Bogor menunjukkan bahwa kelompok dengan kadar CD4<200 berisiko 8,54 kali untuk terkena TB dibanding kelompok dengan kadar CD4>500. Selain itu, penelitian ini menjelaskan bahwa dari nilai PR beberapa kategori kadar CD4, terdapat dose-response relationship, yaitu semakin berkurangnya kadar CD4 maka terdapat peningkatan proporsi TB yang ditemukan. ${ }^{(14)}$ Namun demikian, pada analisis Multivariat tahap awal, jumlah CD4 <200/mm ${ }^{3}$ menurunkan odds 
terjadinya infeksi oportunistik tuberkulosis dengan OR 0,88 (95\% Cl: $0,22-3,43)$, tapi tidak bermakna.

Odds terjadinya infeksi oportunistik tuberkulosis 2,14 kali lebih besar pada pasien HIV dengan jumlah viral load $>1000 / \mathrm{ml}$, walaupun tidak bermakna. Penelitian ini konsisten dengan sebuah penelitian terkait hubungan viral load dengan penyakit oportunistik pada pasien HIV di The AIDS Support Organization (TASO) yang menunjukkan bahwa odds terjadinya infeksi oportunistik tuberkulosis 3,8 kali lebih besar pada pasien HIV yang memiliki viral load terdeteksi $(>1000 / \mathrm{ml}) .{ }^{(16)}$ Penelitian lain dengan desain studi kohort menunjukkan bahwa jumlah viral load $>1000 / \mathrm{ml} 1,41$ kali lebih berisiko untuk terkena infeksi oportunistik tuberkulosis $(95 \% \mathrm{Cl}: 1,15-$ $1,75, p<0,001)$. Hal ini terjadi karena peningkatan viral load dapat menyebabkan terjadinya imunosupresi pada pasien sehingga lebih rentan untuk terkena infeksi oportunistik tuberkulosis. ${ }^{(17)}$

Dalam analisis bivariat, pendidikan rendah meningkatkan odds terjadinya infeksi oportunistik tuberkulosis sebesar 3,16 kali. Sebuah penelitian di salah satu RS Pemerintah Bogor yang menunjukkan bahwa kelompok tingkat pendidikan rendah 1,77 kali lebih berisiko $(95 \% \mathrm{Cl}: 1,16-2,70)$ untuk terkena tuberkulosis daripada kelompok tingkat pendidikan tinggi. Pendidikan diperkirakan mempengaruhi pola pikir dan perilaku seseorang terhadap kesehatan dan kebersihan diri. Dalam hal ini, pendidikan dapat mempengaruhi seseorang dalam melakukan tindakan pencegahan terhadap infeksi tuberkulosis. ${ }^{(14)}$ Kategori pendidikan rendah dalam penelitian ini terdiri dari pasien HIV yang belum sekolah dan yang memiliki pendidikan SD (Sekolah Dasar), namun demikian hubungan pendidikan dengan kejadian infeksi oportunistik tuberkulosis tidak bermakna dengan analisis multivariat.

Hubungan status bekerja dengan kejadian infeksi oportunistik tuberkulosis tidak bermakna pada analisis multivariat, namun odds terjadinya infeksi oportunistik tuberkulosis 1,30 kali lebih besar pada pasien HIV yang tidak bekerja. Hasil penelitian ini sesuai dengan hasil penelitian case control di Khartoum State, Sudan yang menyatakan bahwa pasien HIV yang tidak bekerja memiliki odds infeksi tuberkulosis 2,53 kali lebih besar (95\% Cl: 1,26 - 5,03). Seseorang yang bekerja dianggap memiliki pola pikir dan perilaku yang lebih baik terhadap kesehatan, khususnya dalam melakukan pencegahan terhadap 
infeksi-infeksi yang mungkin terjadi seperti infeksi tuberkulosis. ${ }^{(12)}$

Hubungan perilaku seks berisiko dengan kejadian infeksi oportunistik tuberkulosis juga tidak bermakna, namun odds terjadinya infeksi oportunistik tuberkulosis 1,86 kali lebih besar pada pasien HIV heteroseksual. Hasil penelitian di Korea Selatan juga menunjukkan bahwa tidak ada hubungan yang bermakna antara perilaku seks dengan infeksi oportunistik, termasuk infeksi oportunistik tuberkulosis dengan nilai $\mathrm{p}=0,89 .{ }^{(18)}$ Selain itu, studi case control di Tehran, Iran melalui analisis bivariat menunjukkan bahwa heteroseksual meningkatkan risiko TB lebih daripada jenis transmisi seksual lainnya (Homoseksual dan Biseksual), yaitu dengan OR 2,72 (95\% Cl : 1,53-4,83) dan nilai $p 0,001 .^{(19)}$

Hasil analisis bivariat dengan uji Chi Square menunjukkan bahwa hubungan antara transfusi darah dengan kejadian infeksi oportunistik tuberkulosis tidak bermakna dengan $\mathrm{OR}=2,01 \quad(95 \% \mathrm{Cl}: \quad 0,28-14,43 ;$ $p=0,604)$. Hasil yang sama juga dihasilkan dari sebuah penelitian di 19 rumah sakit di Korea Selatan bahwa tidak ada hubungan yang bermakna antara transfusi darah dengan kejadian infeksi oportunistik, termasuk infeksi oportunistik tuberkulosis, yaitu dengan nilai p 0,89. ${ }^{(18)}$ Selain itu, studi case control di Tehran, Iran melakukan analisis bivariat hubungan transfusi darah dengan infeksi oportunistik tuberkulosis. Hasil analisis bivariat menunjukkan bahwa pasien HIV yang melakukan transfusi darah meningkatkan odds terjadinya infeksi oportunistik tuberkulosis sebesar 1,78 kali, tetapi tidak ada hubungan yang bermakna secara statistik antara transfusi darah dengan tuberkulosis $(p=$ 0,26). (19) $^{(19}$

Hasil analisis bivariat dengan uji Chi Square menunjukkan bahwa hubungan antara penggunaan napza suntik dengan kejadian infeksi oportunistik tuberkulosis tidak bermakna dengan OR=3,08 $(95 \% \mathrm{Cl}$ : 0,86-11,08; $p=0,091$ ). Studi kohort di Korea Selatan tahun 2006-2013 juga menyatakan bahwa tidak ada hubungan yang bermakna antara penggunaan napza suntik dan kejadian infeksi oportunistik tuberkulosis dengan nilai $p=0,09 .{ }^{(18)}$ Selain itu, Studi case control mengenai faktor-faktor yang berhubungan dengan terjadinya infeksi tuberkulosis pada ODHA di Tehran, Iran, menunjukkan bahwa penggunaan napza suntik dapat meningkatkan terjadinya infeksi tuberkulosis, tetapi 
hubungan ini juga tidak bermakna secara statistik. ${ }^{(19)}$

Dalam pelaksanaannya, penelitian ini memiliki kekuatan serta keterbatasan. Kekuatan dalam penelitian ini adalah besar sampel yang sudah memenuhi besar sampel minimal dengan kekuatan penelitian untuk menunjukkan ada hubungan antar variabel sebesar $80 \%$. Sedangkan, kelemahan dalam penelitian ini adalah terbatasnya variabel yang digunakan karena disesuaikan dengan variabel yang tersedia dalam formulir register pra-ART dan rekam medis. Selain itu, penelitian ini hanya bisa digeneralisasikan pada populasi pasien HIV/AIDS di RSPI Prof. Dr. Sulianti Saroso, belum mampu digeneralisasikan dalam populasi yang lebih luas.

Hasil dari penelitian ini diharapkan dapat memberikan data dan gambaran yang berguna untuk meningkatkan pelaksanaan skrining awal TB dalam program pencegahan infeksi oportunistik tuberkulosis pada pasien HIV/AIDS di RSPI Prof. Dr. Sulianti Saroso.

\section{Kesimpulan}

Stadium HIV merupakan variabel determinan kejadian infeksi oportunistik tuberkulosis pasien HIV/AIDS di RSPI Prof. Dr. Sulianti Saroso tahun 20152019, yaitu pasien HIV yang berada pada stadium akhir (stadium III stadium IV).

\section{Saran}

Diperlukan skrining awal mendeteksi TB pada setiap stadium HIV khususnya pada stadium lanjut (IIIIV) yang melakukan kunjungan di klinik Pokja, serta melakukan pemeriksaan rutin CD4 dan viral load secara rutin setiap 6 bulan sekali.

\section{Ucapan Terima Kasih}

Peneliti mengucapkan terima kasih kepada Direktur Utama RSPI Prof. Dr. Sulianti Saroso beserta seluruh jajaran Direksi atas izin yang diberikan sehingga peneliti dapat melakukan penelitian ini. Selain itu, peneliti juga mengucapkan terima kasih kepada seluruh pihak yang memberikan bimbingan dan dukungan dalam penelitian ini.

\section{Daftar pustaka}

1. Kementerian Kesehatan RI. Laporan Situasi Perkembangan HIV/AIDS dan PIMS di Indonesia Tahun 2018. Direktorat Jenderal Pengendali Penyakit dan Penyehatan Lingkung [Internet]. 2018;1-30. Available from: https://www.cambridge.org/core/pro duct/identifier/CBO9781107415324 A009/type/book_part 
2. WHO. HIV/AIDS [Internet]. 2019 [cited 2019 Nov 14]. Available from: https://www.who.int/newsroom/fact-sheets/detail/hiv-aids

3. Kementerian Kesehatan RI. Strategi dan Rencana Aksi Nasional 20152019 Penanggulangan HIV dan AIDS di Indonesia. 2015.

4. UNAIDS. Global HIV \& AIDS statistics - 2019 fact sheet [Internet]. 2019. Available from: https://www.unaids.org/sites/default/ files/media_asset/UNAIDS_FactSh eet_en.pdf

5. UNAIDS. Treatment Cascade. 2018;2018. Available from: http://aidsinfo.unaids.org/

6. CDC. About HIV/AIDS | HIV Basics | HIV/AIDS. Centers for Disease Control and Prevention. 2018.

7. Kementerian Kesehatan RI. Program Pengendalian HIV AIDS dan PIMS [Internet]. 2017. Available from: http://siha.depkes.go.id/portal/ files_upload/BUKU_3_PENGENDA LIAN_HIV_COLOR_A5_15x21_cm. pdf

8. WHO. Tuberculosis [Internet]. 2019. Available from: https://www.who.int/ en/news-room/fact-sheets/detail/ tuberculosis

9. Lubis ZD. Gambaran Karakteristik Individu dan Faktor Risiko Terhadap Terjadinya Infeksi
Oportunistik pada Penderita HIV/AIDS di Rumah Sakit Penyakit Infeksi Sulianti Saroso Tahun 2011. Fakultas Kesehatan Masyarakat UI. 2012.

10. Roselinda, Setiawaty V. The stages of HIV infection and the risk of opportunistic Tuberculosis infection. Heal Sci J Indones [Internet]. 2015;6(2):121-5. Available from: https://media.neliti.com/media/publi cations/63050-EN-the-stages-ofhiv-infection-and-the-risk.pdf

11.Pusat Data dan Informasi Kemenkes RI. InfoDATIN [Internet]. 2018. Available from: https://pusdatin. kemkes.go.id/resources/download/p usdatin/infodatin/infodatintuberkulosis-2018.pdf

12. Awadalla H, El-Samani F, Soghaier MA, Makki M. Risk Factors Associated with the Development of Tuberculosis Among HIV-Infected Patients in Khartoum in 2010. AIMS Public Heal. 2015;2(4):784-92.

13.Pathmanathan I, Dokubo EK, Shiraishi RW, Agolory SG, Auld AF, Onotu D, et al. Incidence and predictors of tuberculosis among HIV-infected adults after initiation of antiretroviral therapy in Nigeria, 2004-2012. PLoS One; San Fr [Internet]. 2017; Available from: https://www.ncbi.nlm.nih.gov/pmc/ar 
ticles/PMC5345814/pdf/pone.01733 09.pdf

14. Karimaa UQ, Sudaryo MK, Kiptiyah NM. Prediktor Kejadian TB pada ODHA di Salah Satu RS Pemerintah Bogor, Tahun 20142016. J Epidemiol Kesehat Indones. 2017;1:25-34.

15. Dalbo M, Tamiso A. Incidence and Predictors of Tuberculosis among HIV/AIDS Infected Patients: A FiveYear Retrospective Follow-Up Study. Adv Infect Dis. 2016;06(02):70-81.

16. Ekwaru JP, Campbell J, Malamba S, Moore DM, Were W, Mermin J. The effect of opportunistic illness on HIV RNA viral load and CD4+ T cell count among HIV-positive adults taking antiretroviral therapy. J Int AIDS Soc [Internet]. 2013; Available from: https://www.ncbi. nlm.nih.gov/pmc/articles/PMC3615 176/

17. Fenner $L$, Atkinson $A$, Boulle $A$, Fox MP, Prozesky H, Zürcher K, et al. HIV viral load as an independent risk factor for tuberculosis in South Africa: collaborative analysis of cohort studies. J Int AIDS Soc [Internet]. 2017;20(21327). Available from: https://www.ncbi.nlm.nih.gov/pmc/ articles/PMC5515052/pdf/zias-201340611.pdf

18. Jeong $\operatorname{Kim} \mathrm{Y}$, Woo JH, Kim MJ, Park DW, Song J-Y, Kim SW, et al. Opportunistic diseases among HIV-infected patients: a multicenter-nationwide Korean HIV/AIDS cohort study, 2006 to 2013. Korean J Intern Med [Internet]. 2016;31:953-60. Available from: https://www.ncbi .nlm.nih.gov/pmc/articles/PMC501 $6273 /$

19. Molaeipoor L, Poorolajal J, Mohraz $\mathrm{M}$, Esmailnasab N. Predictors of tuberculosis and human immunodeficiency virus coinfection: a case-control study. Epidemiol Heal. 2014;36 (e2014024). 